was made by Prüfer and Meyerhof (Der Islam, 1916). The Medical Axioms exist also in at least two mediaeval Latin versions, one probably by Constantine Africanus (11th century), the other probably by Gerard of Cremona (12th century).

The Medical Axioms deal with dietetics, pathology, diagnosis and therapeutics, excluding anatomy, physiology and surgery. (We know, however, that Mesue wrote on anatomy from actual dissection.) The basis is Galenic (" humoral" pathology, etc.). There is a tendency to an intellectualist approach, but Mesue's practice was based on experience and common sense as well as theory. One finds hardly a trace of superstitious or magical remedies, though there are occasional errors of fact. No reference is made to drastic remedies like the "ustio Arabica" of European doctors, as late as the 17th century (Hyrtl). On the whole this work evidences a sober intelligence, and here and in statements by Hunain $b$. Ishāq in his Letter on the Translations of Galen we see a different Mesue from the sardonic figure of anecdotes in Ibn abi Ussaibi'ah. As the earliest Arabic medical writer known to them, he is sometimes called the " Evangelist of medicine" by the Latins. The date of the Axioms is circa 830 .

\title{
The Curve of Cultural Interchange Between China and the West
}

By D. JUSTIN SCHOVE, B.Sc.

The historical geography of trade routes is important in the early history of science. Cultural communications between China and the West took place especially along the "Silk Road" which led by the Jade Gate and the Tarim Basin to North Persia and the Fertile Crescent. A graph of travel along this route compiled from miscellaneous sources had been published recently ${ }^{1}$.

In the 6th century B.C. diffusion of ideas was taking place along this route especially from West to East. Thus, Babylonian star observations had reached China at least by c. 525 B.C. ; iron reached China by the same route in the same century and is specifically mentioned by 513 B.C. Shortly afterwards other Western ideas such as the ox-drawn plough and coffins as in Egypt are adopted in China. Mounted archers reached China before 300 B.C. and cavalry ${ }^{2}$ soon replaced chariotry in warfare all over Eurasia; in China c. 200 B.C., but in Britain not until the defeat of Boadicea. Pythagorean musical ratios and the statement of the "theorem" ascribed to him reach China in the late 3rd century B.C. Meanwhile the use of gold and the ideas of alchemy based on Babylonian chemistry, as Dubs has shown, ${ }^{3}$ had developed in China about the 4 th century B.C.

The known development of the Silk Road took place from 200 B.C. to A.D. 300. Curves (shown) of Western and Chinese science indicated an over-all tendency to decline at Alexandria and to increase in China, where in the 2 nd century A.D. the inventions of paper and a seismograph were developed.

About A.D. 300 unrest on the steppes seriously interfered with the Silk Road and with science both in the West and the East. China and the West

1 D. Justin Schove. Chinese Raininess Through the Centuries. Meterological Magazine, London, 78, 1948, p. 14.

2 Professor Dubs has pointed out that cavalry in the modern sense--horsemen who can use a sword or lance-arose only after the invention of the stirrup. Cf. K. A. Wittfogel and C. S. Feng, History of Chinese Society : Liao pp. 505-507.

- Professor H. H. Dubs. The Beginnings of Alcheny. Isis 38, 1947, 62.86. 
began, especially from A.D. 400 (when the sea route from South China also became important), to depend on India for their cultural intercourse. China had partly ${ }^{4}$ depended on the West for glass as the West depended on China for silk. The art of glass-making was reintroduced to the Chinese by the IndoScythians in the 5th century and in the 6th century the silkworm was concealed in a bamboo cane and introduced to the West, probably by Indian monks.

The inflow of Indian ideas to China at this time was terrific. Religion and Art were perhaps more important than Science, but from c. 440 there occurred a second period of Chinese Science stimulated by fresh ideas received from India. A graph of the accuracy of $\Pi$ in China shows that in this period and especially in the early part it was better known than at any other time before the arrival of modern European mathematics. After A.D. 650 Science declined generally, not only in India itself but also in the Far East and the West.

About A.D. 750 the Chinese invention of paper was received in Mesopotamia and helped to stimulate the scientific renascence which began at Baghdad shortly afterwards, and in the great period of which $c$. 820s John Mesue flourished. Meanwhile Chinese ideas on Alchemy had been returning via the Silk Road and cross-fertilizing with the chemistry of the Fertile Crescent to produce under the Arabs medieval alchemy proper.

In the 13th century cultural interchange began on a vast scale in the days of the Pax Tartarica and some of the results at Pekin and Maragha have been discussed recently by Dr. Martin Johnson in his Art and Scientific Thought. The fruits were, however, very short-lived.

In the 16th century ideas began to pass by the sea route, but in the 18th century Chinese influence on the Arts of Europe was very considerable. Leibniz had suggested that Chinese missionaries should be sent to Europe and Wolff was expelled from Halle for an address in praise of Confucius, but by that time most of the scientific heritage of China had already reached Europe.

4 Professor Goodrich has pointed out that a Chinese-made glass (containing barium) is widely distributed in the fifth-third centuries B.C. in North China. See Bull. Mus. Far Eastern Antiq. No. 10, 1938, 1-64. Iron appears to have been developed in the Wu (Soochow) area of N. E. China probably about the sixth-fifth centuries B.C.

\title{
Bartolomeo Telioux and the Early History of the Thermometer
}

\author{
By J. A. CHALDECOTT, M.Sc., A.Inst.P. \\ (Assistant Keeper, Science Museum) \\ ABSTRACT of Paper read on 26th May, 1952
}

An illustration of Santorio's thermometer which appears in Biancani's Sphaera Mundi (Bologna, 1620) was previously thought to be the first illustration of a thermometer of the single-bulbed pattern. However, a recent examination of a manuscript written by Bartolomeo Telioux and now preserved in the Library of the Arsenal, Paris (MS. No. 8525), has revealed that another illustration of an instrument of this type existed as early as 1611. Additional interest attaches to this illustration by virtue of the fact that a thermometer scale is also depicted behind the instrument, whereas the first instrument of Santorio (1611) was without a scale. Telioux's scale is of eight degrees and each degree is further divided into sixty minutes, with graduations at tenminute intervals, a system of scaling possibly suggested by analogy with the graduation of astronomical instruments. 